\title{
The Black Hills Hydrology Study
}

\author{
—By Janet M. Carter, Daniel G. Driscoll, and Joyce E. Williamson
}

\section{Introduction}

The Black Hills area is an important resource center that provides an economic base for western South Dakota through tourism, agriculture, timber, and mineral resources. Water originating from the area is used for municipal, industrial, agricultural, and recreational purposes throughout much of western South Dakota. The Black Hills area also is an important recharge area for aquifers in the northern Great Plains.

Population growth, resource development, and periodic droughts have the potential to affect the quantity, quality, and availability of water within the Black Hills area. Because of this concern, the Black Hills Hydrology Study was initiated in 1990 to assess the quantity, quality, and distribution of surface water and ground water in the Black Hills area of South Dakota. This long-term study was a cooperative effort between the U.S. Geological Survey (USGS), the South Dakota Department of Environment and Natural Resources, and the West Dakota Water Development District, which represented various local and county cooperators. This fact sheet describes the Black Hills Hydrology Study and the major findings of the study. More detailed summaries are provided in a lay-reader summary (Carter and others, 2002) and in a technical summary (Driscoll and others, 2002).

\section{Overview of Study}

The Black Hills Hydrology Study was initiated in 1990 as a partnership among several local, State, and Federal agencies. The study area for the Black Hills Hydrology Study includes portions of

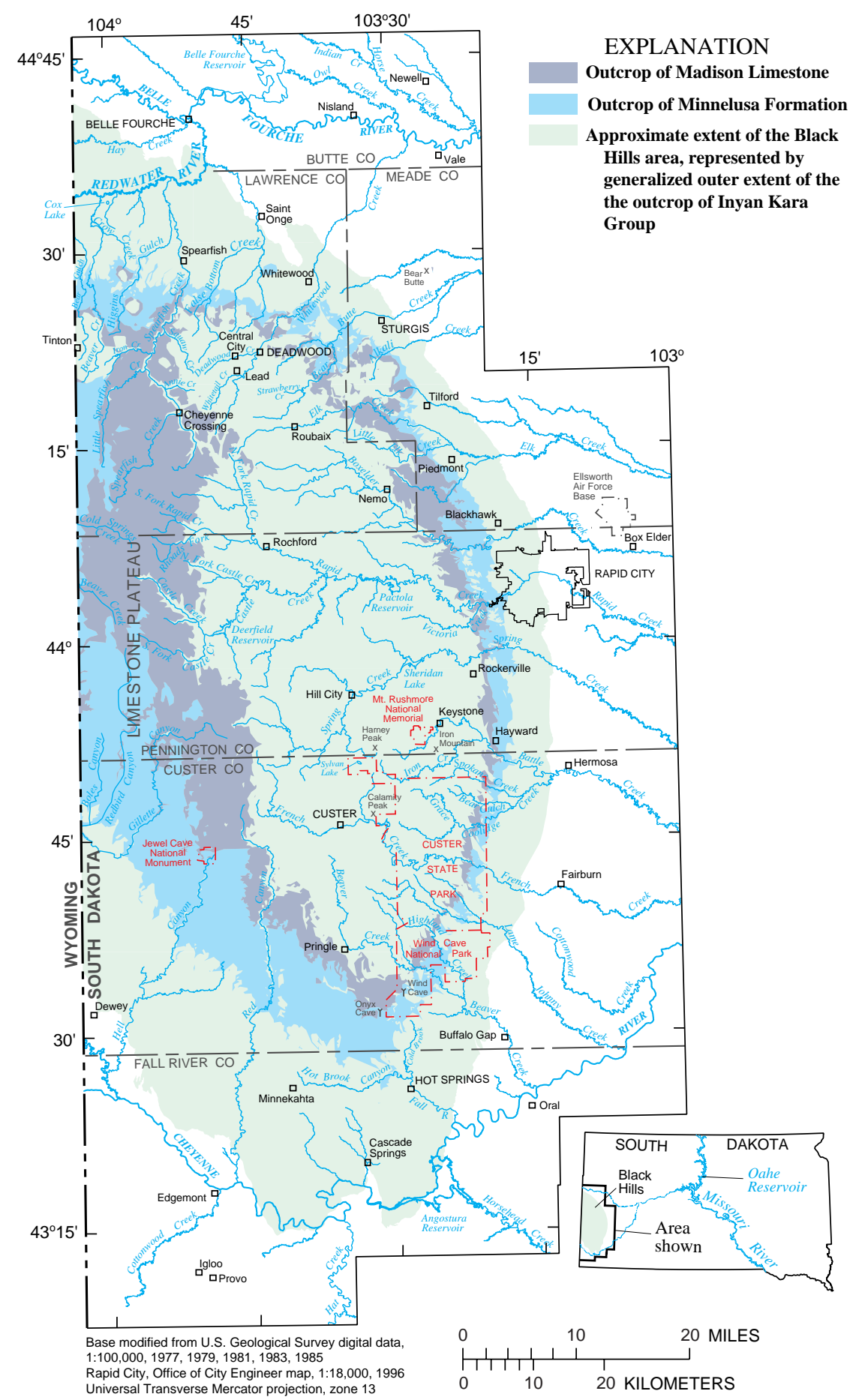

Figure 1. Area of investigation for the Black Hills Hydrology Study. 
six counties in the Black Hills area of South Dakota (fig. 1). Outcrops of the Madison Limestone and Minnelusa Formation in South Dakota, which are areas where these geologic formations occur at the land surface, are shown in figure 1. The generalized outer extent of the outcrop of the Inyan Kara Group, which approximates the outer extent of the Black Hills area, also is shown in figure 1 .

The purpose of the Black Hills Hydrology Study was to assess the quantity, quality, and distribution of surface water and ground water in the Black Hills area of South Dakota. The study was designed as a regional assessment of the water resources and was not designed to address site-specific issues. Because the Black Hills area is an important recharge area for several regional bedrock aquifers and various local aquifers, the study concentrated on describing the hydrologic significance of selected bedrock aquifers. The major aquifers in the Black Hills area are the Deadwood, Madison, Minnelusa, Minnekahta, and Inyan Kara aquifers. The highest priority was placed on the Madison and Minnelusa aquifers, which are widely used and interact extensively with the surface-water resources of the area.

The study consisted of two primary phases-data collection and interpretation. An extensive network consisting of

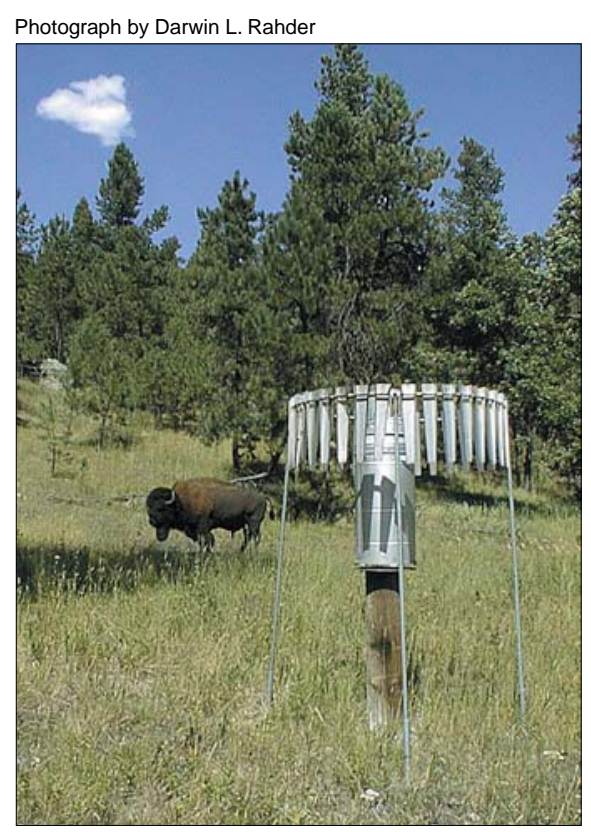

The precipitation gage Mt. Coolidge near Custer was operated from 1990-98. about 71 observation wells, 94 precipitation gages, and 60 streamflow-gaging stations was used during the datacollection phase. Critical components of this network (primarily observation wells and selected streamflow-gaging stations) are being maintained for longterm purposes through a cooperative program between the USGS and local and State cooperators.

A series of 21 reports and 11 maps have been published as part of the study. Hydrologic data collected during the study have been published in various data reports. Maps (1:100,000 scale) have included a hydrogeologic unit map for the study area, structure-contour maps for five geologic formations that contain major aquifers, and potentiometric maps for these major aquifers. Interpretive reports have addressed water quality and hydrologic conditions for surface water and ground water. Many of the interpretive reports have dealt specifically with the Madison and Minnelusa aquifers, which were a primary focus of the study. Additional information concerning the study and study products is available at http:// sd.water.usgs.gov/projects/bhhs/ BHHS.html.

\section{Description of Study Area}

The study area for the Black Hills Hydrology Study (fig. 1) consists of the topographically defined Black Hills and adjacent areas located in western South Dakota. The Black Hills are situated between the Cheyenne and Belle Fourche Rivers. The Belle Fourche River is the largest tributary to the Cheyenne River. The study area includes most of the larger communities in western South Dakota and contains about one-fifth of the State's population.

\section{Climate}

The overall climate of the Black Hills area is continental, which is characterized generally by low precipitation amounts, hot summers, cold winters, and extreme variations in both precipitation and temperatures. Local climatic conditions are affected by topography, with generally lower temperatures and higher precipitation at the higher altitudes.
Long-term trends in precipitation for water years 1931-98 for the study area are illustrated in figure 2; a water year is the 12-month period, October 1 through September 30, and is designated by the calendar year in which it ends. Annual precipitation for the study area averages 18.61 inches and has ranged from 10.22 inches in water year 1936 to 27.39 inches in water year 1995 . The middle to late 1990's stand out as the wettest period since 1931, which has caused potential for bias towards wet conditions in the data collected in the Black Hills during this period. This potential bias has been addressed in the analysis of hydrologic data throughout the course of the study, and has been balanced to some extent by relatively dry conditions during the late 1980's and early 1990’s.

\section{Hydrogeologic Setting}

Throughout geologic time, the Black Hills area has experienced frequent periods of inundation by seas, extended erosion, mountain building, and intrusion by igneous rocks; thus, the hydrogeology of the study area is very complex. The Black Hills uplift formed as an elongated dome about 60 to 65 million years ago. The oldest geologic units in the study area are the Precambrian crystalline (igneous and metamorphic) rocks (not shown in fig. 1), which are exposed in the central core of the Black Hills, extending from near Lead to south of Custer. The Precambrian rocks generally have low permeability; however, localized aquifers occur in many locations in the crystalline core of the Black Hills

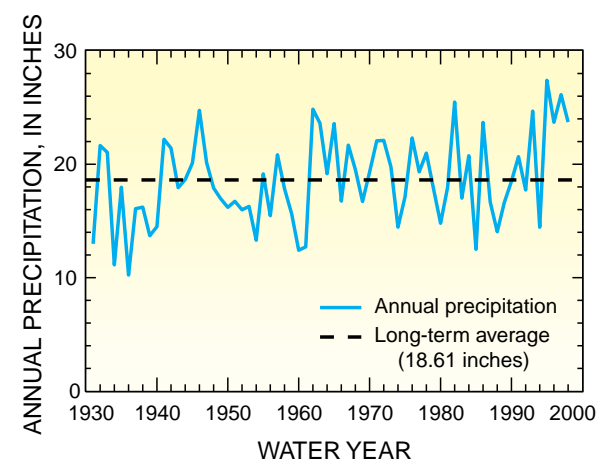

Figure 2. Long-term trends in precipitation for the Black Hills area, water years 1931-98. 
where secondary porosity and permeability have resulted from fracturing and weathering of the rocks.

Surrounding the Precambrian crystalline core is a layered series of sedimentary rocks including limestones, sandstones, and shales that are exposed in roughly concentric rings around the uplifted flanks of the Black Hills, as shown by the outcrops of the Madison Limestone and Minnelusa Formation (fig. 1). The more permeable of these sedimentary rocks - the Deadwood Formation, Madison Limestone, Minnelusa Formation, Minnekahta Limestone, and Inyan Kara Group — contain major aquifers that are able to store and transmit large quantities of water and are used extensively for water supplies within and beyond the study area. Alluvial deposits along streams also commonly are used as local aquifers.

The hydrologic setting of the Black Hills area is schematically illustrated in figure 3. Individually, the major aquifers generally are separated by confining layers, which are composed of less permeable rocks, or by relatively impermeable layers within the individual units. The aquifers and confining units generally dip away from the flanks of the Black Hills (fig. 3). In general, ground-water

Photograph by Van A. Lindquist, West Dakota Water Development District

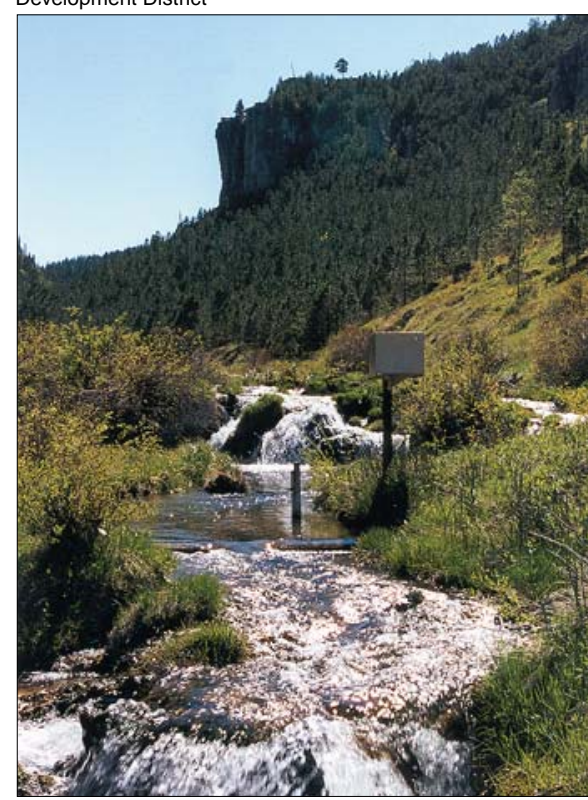

Headwater springflow at the eastern edge of the Limestone Plateau provides flow to Rhoads Fork.

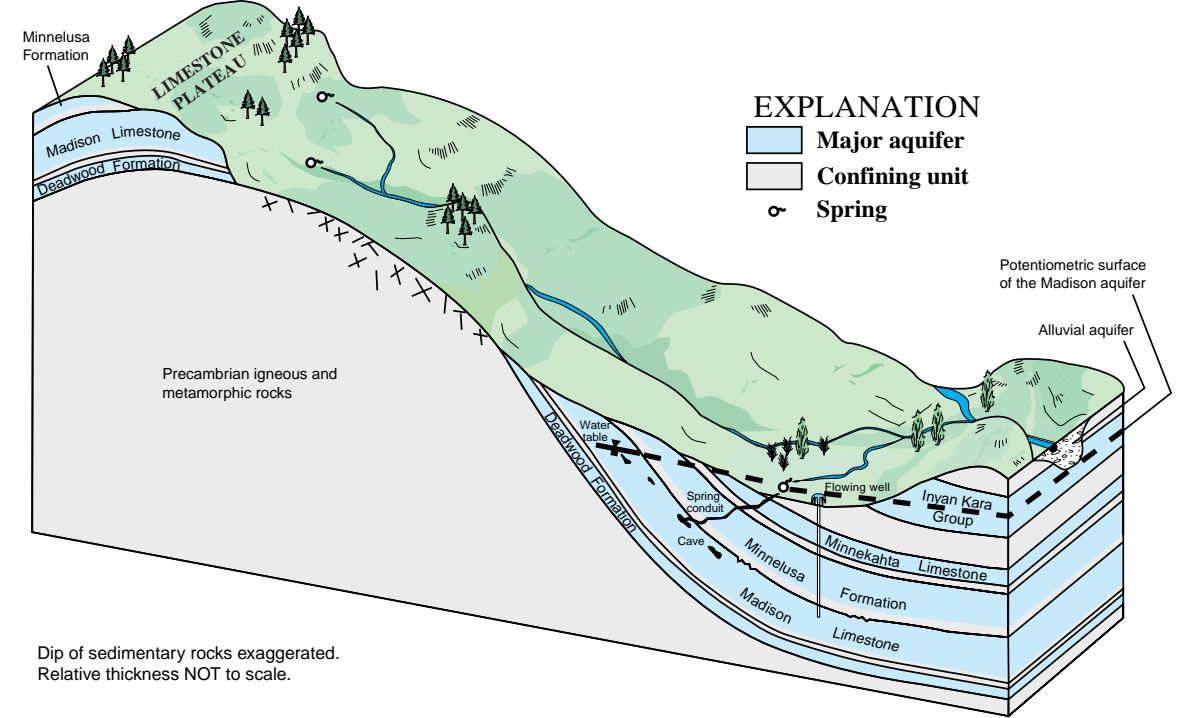

Figure 3. Schematic showing simplified hydrologic setting of the Black Hills area.

flow in these aquifers is radially away from the central core of the Black Hills. The aquifers primarily receive recharge from infiltration of precipitation on outcrops, and the Madison and Minnelusa aquifers also receive substantial recharge from streamflow losses.

Confined (artesian) conditions generally exist within the major aquifers, in locations where an upper confining layer is present. Under confined conditions, water in a well will rise above the top of the aquifer in which it is completed. Flowing wells will result when drilled in areas where the potentiometric surface (level to which water will rise) is above the land surface. Flowing wells and artesian springs that originate from confined aquifers are common around the periphery of the Black Hills.

Surface water in the Black Hills area is highly influenced by geologic conditions, and five hydrogeologic settings have been identified that have distinctive influences on streamflow and surfacewater quality. The five settings, which are shown in figure 4 , are represented by four areas because two of the settings (loss zone and artesian spring) are considered to share a common area.

Numerous headwater (water-table) springs, originating primarily from the Madison and Minnelusa aquifers, occur in the limestone headwater setting, which is a high-altitude area of generally low relief in the western part of the study area known as the "Limestone Plateau" (fig. 4). Most of the headwater springs occur near the eastern edge of the Limestone Plateau and provide base flow for many Black Hills streams. These streams flow across the Precambrian igneous and metamorphic rocks in the crystalline core setting.

The loss zone setting (fig. 4) consists of areas that are heavily influenced by streamflow losses. Most streams generally lose all or part of their flow as they cross the outcrop of the Madison Limestone. Karst features of the Madison Limestone, including collapse features, sinkholes, and solution features such as caves, are responsible for the Madison aquifer's large capacity to accept recharge from streamflow. Large streamflow losses also occur in many locations within the outcrop of the Minnelusa Formation, and limited losses probably also occur within the outcrop of the Minnekahta Limestone (not shown in fig. 1).

Large artesian springs originating primarily from the Madison and Minnelusa aquifers occur in many locations downgradient from these loss zones. Thus, the loss zone and artesian spring settings are represented by the same area (fig. 4). These artesian springs provide an important source of base flow in many streams beyond the periphery of the Black Hills. 
No artesian springs are known to be located beyond the outcrop of the Inyan Kara Group; thus, the area beyond this outcrop is considered to be the exterior setting (fig. 4).

\section{Summary of Major Findings}

Numerous findings have been published in various reports produced for the Black Hills Hydrology Study, of which several are highlighted in this fact sheet. For more information, readers are referred to two summary reports for the study by Carter and others (2002) and Driscoll and others (2002).

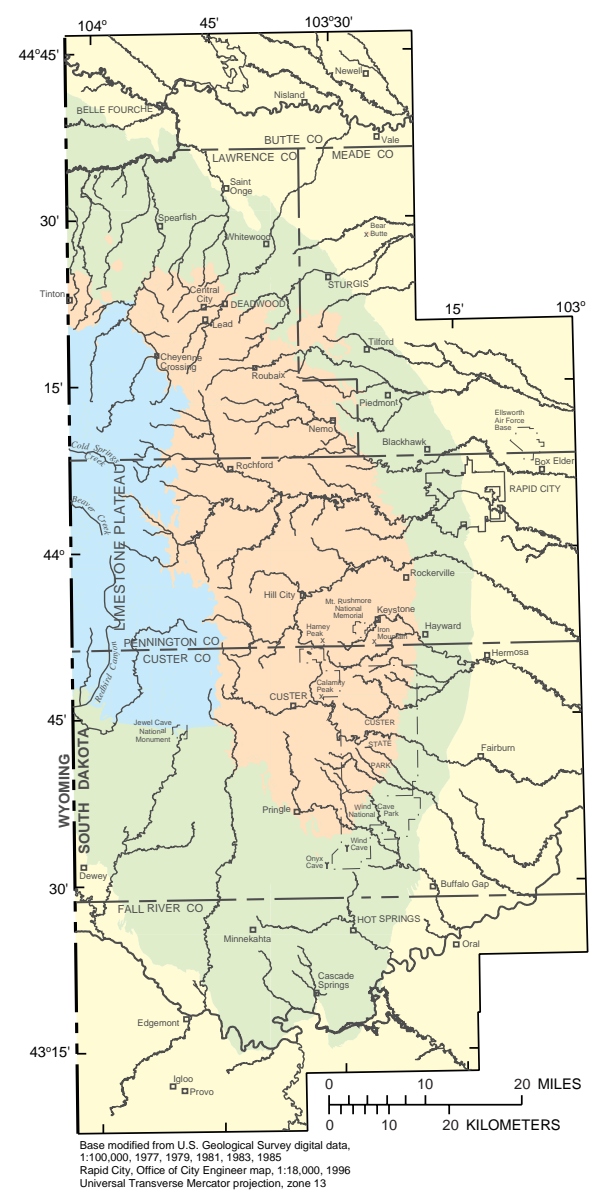

\footnotetext{
EXPLANATION

Hydrogeologic settings

Limestone headwater

Crystalline core

Loss zone and artesian spring-Bounded by inner extent of Madison Limestone and outer extent of Inyan Kara Group

Exterior
}

Figure 4. Hydrogeologic settings for the Black Hills area.
Water-level records have been collected for 71 observation wells completed in bedrock aquifers and 2 cave sites in the Madison Limestone, providing useful information for hydrologic analyses and management of water resources. Water levels can be affected by several factors including pumping of nearby wells and climatic conditions. Long-term water-level declines could have various effects, including changes in ground-water flow patterns, reduction of springflow, increased pumping costs, and dry wells. A large percentage of the observation wells completed in the Madison and Minnelusa aquifers respond quickly to climatic conditions. Nearly all of the hydrographs for these aquifers show a downward water-level trend prior to 1993, as illustrated in the example hydrographs for a well pair completed in the Madison and Minnelusa aquifers (fig. 5). This downward trend can be partially attributed to dry climatic conditions in the Black Hills area during this period. Precipitation amounts generally were above average after 1993, and water levels increased rapidly (fig. 5) in most wells due to the large recharge capacity of the Madison and Minnelusa aquifers. In general, there is very little indication of declining water levels from ground-water withdrawals in any of the bedrock aquifers in the Black Hills area.

The hydraulic head in the Madison and Minnelusa aquifers is similar at the location for the well pair shown in the example hydrographs (fig. 5) and at various other locations throughout the Black Hills area. However, the hydraulic head in the aquifers can be separated by several hundred feet in some locations.

Hydraulic connection between the Madison and Minnelusa aquifers at some locations in the Rapid City area has been confirmed through aquifer testing and dye tracing (Greene, 1993, 1997). In the Spearfish area, aquifer testing provided no indication of hydraulic connection in the vicinity of the tested wells (Greene and others, 1999). Hydraulic connection is not known at other locations throughout the Black Hills area because aquifer testing has not been performed. Hydraulic connection between the Madison and Minnelusa aquifers probably occurs at many artesian spring locations, and minor leakage probably occurs at many

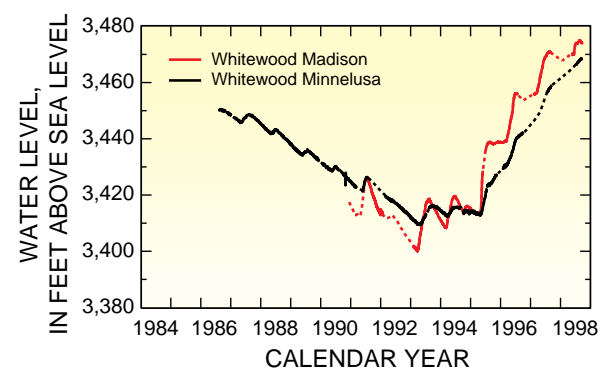

Figure 5. Hydrographs illustrating general similarities in water levels for a Madison/ Minnelusa well pair near Whitewood.

locations where a hydraulic gradient exists between the aquifers. Artesian springflow probably accounts for the largest percentage of leakage that occurs.

Streamflow variability is highly influenced by the hydrogeologic settings shown in figure 4 . For the limestone headwater and artesian spring settings, streamflow variability is small because of the dominance by ground-water discharge. The largest headwater springs are in the Rapid Creek and Spearfish Creek Basins. The largest artesian spring discharge areas are located near the northern and southern parts of the axis of the Black Hills uplift; the single largest discharge area is a complex of springs in the northern Black Hills that includes Cox Lake and Crow Creek. In the crystalline core setting, streamflow characteristics are influenced by direct runoff and by relatively small groundwater discharge, which tends to diminish rather quickly during periods of dry climatic conditions.

In the loss zone setting, most streams provide an important source of recharge to the Madison and Minnelusa aquifers because most streams generally lose their entire flow when crossing outcrops of the Madison Limestone and Minnelusa Formation. Unique loss thresholds (maximum sustainable loss rates) have been determined for individual streams, with measured thresholds ranging from negligible losses for several streams to as much as 50 cubic feet per second $\left(\mathrm{ft}^{3} / \mathrm{s}\right)$ for Boxelder Creek. In the exterior setting, streamflow variability is large because streams are heavily influenced by direct runoff and generally have only minor influence from ground-water discharge. 
Water-quality characteristics for the ground-water and surface-water resources in the Black Hills area were summarized for the study. Water quality of the major aquifers generally is very good in and near outcrop areas but deteriorates progressively with distance from the outcrops. In the Minnelusa aquifer, concentrations of dissolved sulfate vary markedly over short distances, where a zone of active anhydrite dissolution occurs. Most limitations for the use of ground water are related to aesthetic qualities associated with hardness and high concentrations of chloride, sulfate, sodium, manganese, and iron. Very few health-related limitations exist for ground water; most limitations are for substances associated with radioactive decay, such as radon and uranium. In addition, high concentrations of arsenic have been detected in a few samples from the Minnelusa aquifer.

Surface-water quality is distinctively influenced by the hydrogeologic settings (fig. 4). For most streams, concentrations of dissolved solids increase as streamflow decreases. However, for streams in the limestone headwater and artesian spring settings, which are dominated by ground-water discharge, concentrations of dissolved solids have little variability. Most streams generally meet water-quality standards established for designated beneficial uses. The primary exceptions are streams in the exterior setting, which occasionally fail to meet standards for temperature and dissolved oxygen during low-flow conditions. Standards for suspended sediment also have been exceeded in some streams (South Dakota Department of Environment and Natural Resources, 1998).

Human influences have the potential to degrade water quality for both ground water and surface water. For ground water, the potential for contamination can be large because of development on and upgradient of aquifer recharge areas, large secondary porosity, and relatively fast flow velocities. Contamination by septic tanks has been documented for some wells in the Blackhawk, Piedmont, and Sturgis areas (Bartlett and West Engineers, Inc., 1998).

For surface water, various land-use practices can affect water quality. Degradation of water quality from large- scale mining activities has occurred in Annie, Bear Butte, Squaw, and Whitewood Creeks. Approximately 900 abandoned or inactive mines occur throughout the Black Hills area (South Dakota Department of Environment and Natural Resources, 2001). Potential impacts of acid-mine drainage include acidic water and increased concentrations of metals, sulfate, and dissolved solids that can cause detrimental aquatic effects. Efforts are underway by Federal, State, and private individuals and companies to remediate problematic sites. Various agricultural, urban, and suburban activities also can degrade stream quality.

The total volume of recoverable water stored in the major aquifers (including aquifers in the Precambrian rocks) within the study area is estimated as 256 million acre-feet (table 1), which is slightly more than 10 times the maximum storage of Oahe Reservoir on the Missouri River. Although the volume of stored water is very large, water quality may not be suitable for all uses in some parts of the study area, as previously discussed.

Hydrologic budgets provide an accounting of inflows to and outflows from a specified area, such as an aquifer or drainage basin. Hydrologic budgets for ground water and surface water in the study area were developed for water years 1950-98. Of the average annual

Table 1. Estimated volumes of recoverable water in storage for major aquifers in study area

[From Carter and others, 2002]

\begin{tabular}{lc}
\hline \multicolumn{1}{c}{ Aquifer } & $\begin{array}{c}\text { Recoverable } \\
\text { storage } \\
\text { (million } \\
\text { acre-feet) }\end{array}$ \\
\hline Precambrian & 2.6 \\
Deadwood & 30.5 \\
Madison & 62.7 \\
Minnelusa & 70.9 \\
Minnekahta & 4.9 \\
Inyan Kara & 84.7 \\
\hline $\begin{array}{l}\text { Combined storage } \\
\text { for major aquifers }\end{array}$ & 256.3 \\
\hline
\end{tabular}

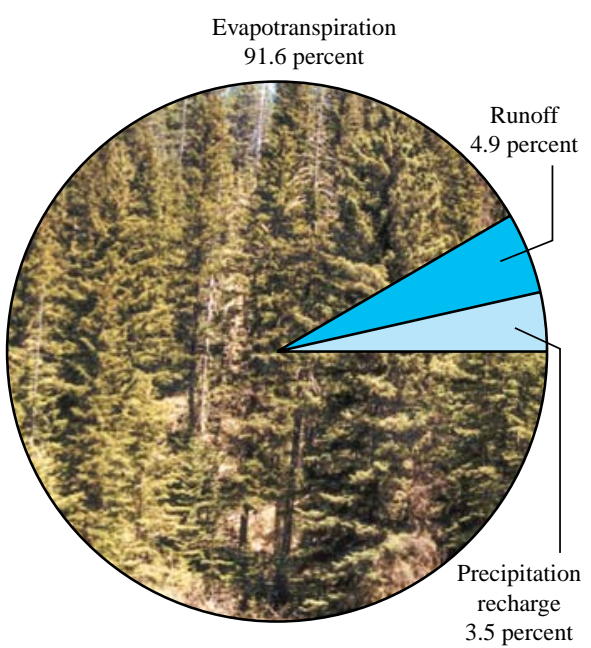

Figure 6. Evapotranspiration, runoff, and precipitation recharge as percentages of average annual precipitation.

precipitation in the study area, about 91.6 percent is returned to the atmosphere via evapotranspiration, about 3.5 percent recharges aquifers in the study area, and about 4.9 percent becomes runoff from the land surface (fig. 6).

The Madison and Minnelusa aquifers dominate the ground-water budgets for the study area. For example, combined average recharge to the bedrock aquifers in South Dakota for 1950-98 was estimated as $348 \mathrm{ft}^{3} / \mathrm{s}$, of which 84 percent recharges the Madison and Minnelusa aquifers. Springflow was estimated as $219 \mathrm{ft}^{3} / \mathrm{s}$, of which 94 percent originates from the Madison and Minnelusa aquifers. Well withdrawals were estimated as $40 \mathrm{ft}^{3} / \mathrm{s}$, of which 70 percent is withdrawn from the Madison and Minnelusa aquifers. Ground-water outflow from the study area was estimated as $89 \mathrm{ft}^{3} / \mathrm{s}$, of which 65 percent occurs in the Madison and Minnelusa aquifers. Artesian springflow is the single largest discharge component for the Madison and Minnelusa aquifers, and accounts for 38 percent of the total discharge from these aquifers.

Large outcrops of the Madison Limestone and Minnelusa Formation occur in the Black Hills of Wyoming and were included in estimating recharge to the Madison and Minnelusa aquifers. Recharge to these aquifers for water years 1931-98 in South Dakota and 


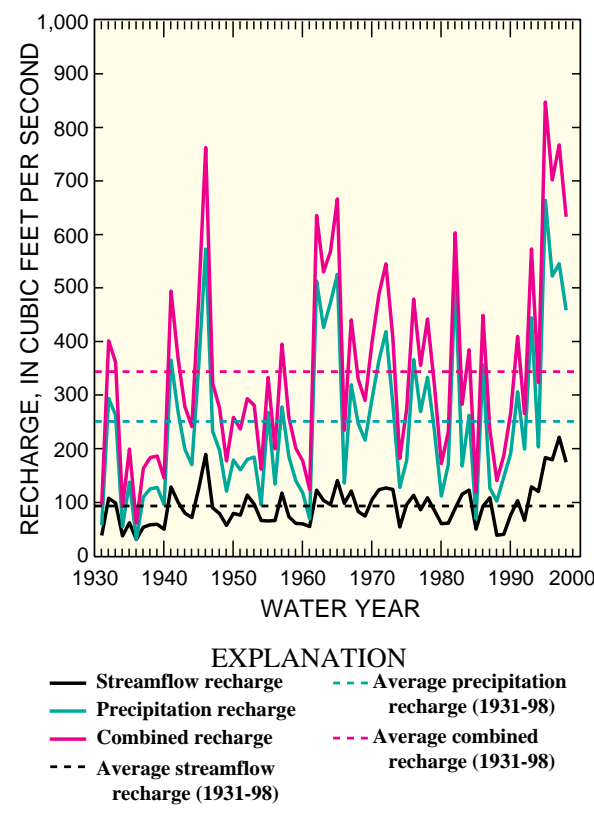

Figure 7. Annual recharge (water years 1931-98) to the Madison and Minnelusa aquifers in the Black Hills of South Dakota and Wyoming (from Carter, Driscoll, and Hamade, 2001). Prolonged periods of below-average recharge occurred during the 1930's and 1950's.

Wyoming averaged about $344 \mathrm{ft}^{3} / \mathrm{s}$. Annual recharge rates were highly variable (fig. 7) and ranged from about $62 \mathrm{ft}^{3} / \mathrm{s}$ in 1936 to about $847 \mathrm{ft}^{3} / \mathrm{s}$ in 1995 .

Total consumptive use within the study area from both ground-water and surface-water resources was estimated as $218 \mathrm{ft}^{3} / \mathrm{s}$, which includes well withdrawals of $40 \mathrm{ft}^{3} / \mathrm{s}$, reservoir evaporation of $38 \mathrm{ft}^{3} / \mathrm{s}$, and consumptive streamflow withdrawals of $140 \mathrm{ft}^{3} / \mathrm{s}$. Net tributary flows, after consumptive streamflow withdrawals, accounted for about $201 \mathrm{ft}^{3} / \mathrm{s}$ in the Cheyenne River drainage basin and about $107 \mathrm{ft}^{3} / \mathrm{s}$ in the Belle Fourche River drainage basin. Thus, streamflow contributions from the study area to the Missouri River amount to about 4 percent of the average flow of the Missouri River where it enters South Dakota.

In the Madison and Minnelusa aquifers, regional flowpaths from the west are largely deflected around the Black Hills. The dominant proportion of water in these aquifers within the study area is recharged within the Black Hills area, with ground-water flow generally radially away from the outcrops. In the
Rapid City area, geochemical analyses indicated that flowpaths in the Madison aquifer are not restricted by surfacewater drainage basins, whereby water recharged in the Boxelder Creek and Spring Creek Basins is recovered by wells in the Rapid Creek Basin. Agedating analyses indicated that groundwater flow velocities in these aquifers are extremely variable.

Artesian springs act as a "relief valve" for the Madison and Minnelusa aquifers and are an important mechanism in controlling water levels in these aquifers. Springflow of many large artesian springs changes very slowly in response to long-term climatic conditions. Artesian springflow could be diminished by large-scale well withdrawals near springs, thus impacting surface-water resources. Large-scale development of the Madison and Minnelusa aquifers has the potential to influence the balance of the unique and dynamic "plumbing system" in the Black Hills area that controls interactions between ground-water levels and artesian springflow.

\section{References}

Bartlett and West Engineers, Inc., 1998, Piedmont Valley water quality assessment study—Final report: Bismarck, N. Dak., Bartlett and West Engineers, Inc. [variously paged].

Carter, J.M., Driscoll, D.G., Williamson, J.E., and Lindquist, V.A., 2002, Atlas of water resources in the Black Hills area, South Dakota: U.S. Geological Survey Hydrologic Investigations Atlas HA 747, 120 p.

Driscoll, D.G., Carter, J.M., Williamson, J.E., and Putnam, L.D., 2002, Hydrology of the Black Hills area, South Dakota: U.S. Geological Survey Water-Resources Investigations Report 02-4094, 150 p.

Greene, E.A., 1993, Hydraulic properties of the Madison aquifer system in the western Rapid City area, South Dakota: U.S. Geological Survey Water-Resources Investigations Report 93-4008, 56 p. 1997, Tracing recharge from sinking streams over spatial dimensions of kilometers in a karst aquifer: Ground Water, v. 35, no. 5, p. 898904.

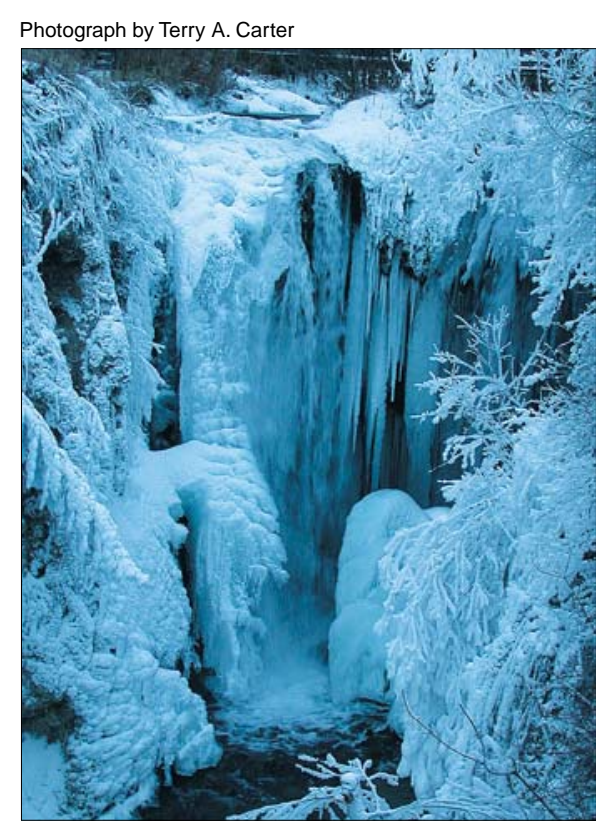

Roughlock Falls along Little Spearfish Creek.

Greene, E.A., Shapiro, A.M., and Carter, J.M., 1999, Hydrogeologic characterization of the Minnelusa and Madison aquifers near Spearfish, South Dakota: U.S. Geological Survey Water-Resources Investigations Report 98-4156, 64 p.

South Dakota Department of Environment and Natural Resources, 1998, The 1998 South Dakota 303(d) waterbody list: Pierre, S. Dak., South Dakota Department of Environment and Natural Resources [variously paged].

-2001, Inactive and abandoned mines in the Black Hills, Minerals and Mining Program: South Dakota Department of Environment and Natural Resources, accessed July 13, 2001, at URL http://www.state.sd.us/ denr/des/mining/acidmine.htm

\section{For more information, please contact:}

\author{
District Chief \\ U.S. Geological Survey \\ 1608 Mt. View Road \\ Rapid City, SD 57702 \\ (605) 355-4560
}

http://sd.water.usgs.gov/projects/ bhhs/BHHS.html 